
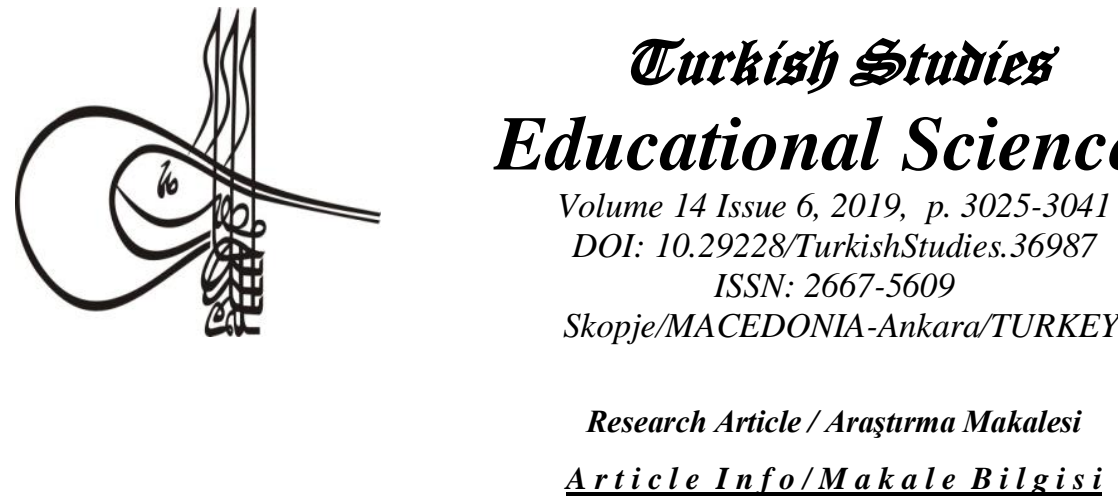

Received/Geliş: 11.09 .2019

an Report Dates/Rapor Tarihleri: Referee 1 (19.11.2019)-Referee 2 (22.11.2019)

This article was checked by iThenticate.
INTERNATIONAL

BALKAN

UNIVERSITY

EXCELLENCE FOR THE FUTURE IBU.EDU.MK

ISSN: 2667-5609

Skopje/MACEDONIA-Ankara/TURKEY

Article Info/Makale Bilgisi

\title{
11-12 YAŞ ÇOCUKLARDA ŞİDDET DEĞİŞKENİNE GÖRE KIRMIZI RENGIN KAVRAMSAL VE SIMGESEL ÇAĞRIŞIMLARI
}

\author{
İran Nihan DEMIREL*
}

\begin{abstract}
Öz
Araştırmanın amac1, 11-12 yaş çocuklarda şiddet değişkenine göre kırmızı rengin kavramsal ve simgesel çağrışımlarını incelemektir. Araştırma, nicel ve nitel araştırma yaklaşımlarının bir arada kullanıldığı karma yöntem araştırma desenlerinden yakınsayan paralel desen yaklaşımıla yürütülmüştür. Araştırmanın çalışma grubunu 11-12 yaş aralığındaki toplam 147 ortaokul 7. sınıf öğrencisi olușturmaktadır. Araștırmanın nicel boyutunda veri toplama aracı olarak kırmızı rengin kavramsal ve simgesel çağrışımları ölçeği ve nitel boyutunda ise, kırmızı rengin kavramsal ve simgesel çağrışımları anket formu kullanılmıştır. Araştırmanın nicel ve nitel boyutundan elde edilen sonuçlara göre, şiddet uyguladığını ifade eden çocuklar kırmızı rengi kavramsal olarak kan, öfke, cinayet, tehlike, kavga, şiddet, güç gibi belirli mesajlar, deneyim ya da fikirler üzerinden değerlendirirken; şiddet uygulamayan çocuklar kırmızı rengi kavramsal olarak, sevgi mutluluk, özgürlük gibi kavramlar üzerinden değerlendirmektedirler. Simgesel olarak ise her iki grupta yer alan çocukların kırmızı rengi Türk Bayrağı, şehit ya da şehit kanı gibi benzer simgeler üzerinden değerlendirdikleri tespit edilmiştir. $\mathrm{Bu}$ doğrultuda kırmızı renk uyaranına verilen tepkilerin kavramsal olarak şiddet değişkeninden etkilendiği ve şiddet eğilimi ile kırmızı rengin çağrışım yaptığı kavramlar arasında doğrudan bir ilişki olduğu belirlenmiştir. $\mathrm{Bu}$ bilgiler ışığında çocuklarla çalışan eğitimcilerin çocuklarda renk bilinci oluşturmak ve renk-duygu ilişkisini kavratmak amacıyla farklı sanatsal yöntem ve tekniklerle ilişkilendirilmiş sınıf içi etkinlikler düzenlemeleri gerektiği düşünülmektedir.
\end{abstract}

Anahtar Kelimeler: Kırmız1 renk, şiddet, kırmız1 rengin kavramsal ve simgesel çağrışımları. 


\title{
CONCEPTIONAL AND SYMBOLIC ASSOCIATIONS OF RED COLOR BASED ON VIOLENCE VARIABLE IN 11-12 YEARS OLD CHILDREN
}

\begin{abstract}
The aim of this study is to determine the conceptional and symbolic associations of red color based on violence variable in 11-12 years old children. The research was conducted with convergent parallel design from mixed method research designs in which quantitative and qualitative research approaches were used together. The study group of the research is composed of 147 secondary schools 7 th grade students aged 11-12 years. In the quantitative dimension of the research, the conceptional and symbolic associations scale of red color were used as data collection tool, while the questionnaire form of conceptional and symbolic associations of red color was used in the qualitative dimension of the research. According to the results obtained from the quantitative and qualitative aspects of the study, children who stated that they applied violence were conceptually evaluated the red color through certain messages, experiences or ideas such as blood, anger, murder, danger, fight, violence, power; non-violent children conceptually evaluate the red color through concepts such as love, happiness and freedom. Symbolically, it was found that the children in both groups evaluated the red color through similar symbols such as Turkish Flag, martyr or martyr blood. In this direction, it was determined that the reactions given to the red color stimulus were affected by the violent tendency. It was also found that there is a direct relationship between the tendency of violence and the psychological effect of red color. It is thought that educators working with children should organize in-class activities related to different artistic methods and techniques in order to create color consciousness in children and to understand color-feeling relation.
\end{abstract}

\section{STRUCTURED ABSTRACT}

\section{Introduction}

Red is perceived as more threatening and dominant on human psychology and behavior than other colors (Wiedemann, Burt, Hill and Barton, 2015). It is believed that the red color gives life energy because the red represents the color of blood and it is seen as a symbol of war, violence and conflict (Küçükşen Öner, 2010). Some research suggests that too much exposure to red encourages violent behavior and lack of focus (Abbasi, Talaei, Talaei and Rezaei, 2014; Bagchi and Cheema, 2013; Hill and Barton 2005; Little and Hill 2007). In this study, it was aimed to determine the conceptional and symbolic associations of red color based on violence variable in 11-12 years old children.

\section{Method}

The research was conducted with convergent parallel design from mixed method research designs. . The study group of the research is composed of 147 secondary school students aged 11-12 who study in the Black Sea Region. Red color' conceptional and symbolic associations 
scale and questionnaire form was used as data collection tools in the research. The t-test was used in the analysis of the data obtained from the quantitative dimension of the study. Qualitative data were analyzed according to the three-stage model (description, classification and association) of Dey (1993).

\section{Findings}

The results of the research showed that children who use violence evaluate the color red conceptually, through specific messages, experiences or ideas compared to children who do not; symbolically, the children in both groups have the same sensory symbols. Findings show that psychological effects of red color on children aged 11-12 years differs in terms of the connotations of red color. Children who stated violence according to this differentiation relate to negative concepts red color such as blood $(f=14)$, anger $(f=11)$, homicide $(f=9)$, violence $(f=7)$, danger ( $f=6)$ and fight $(f=4)$; children who do not use violence are associated with positive concepts red color such as love $(\mathrm{f}=23)$, happiness $(\mathrm{f}=21)$, freedom $(\mathrm{f}=14)$ and liking $(\mathrm{f}=10)$. The views of children aged 11-12 who express violence and not violence on people around them can be regarded as an indication of the psychological differentiation of their emotions and behavior in relation to the tendency of violence in their experience through their own experiences in the reactions they give to color stimuli.

Some of the children who stated that they use violence evaluate themselves with a negative psychology according to the children who stated that they did not use violence points to the conclusion that the concepts related to red color may be affected by the negative emotional reactions in daily life. In this respect, the results of the research show that the meaning and effect of red color is influenced by the feelings, thoughts and behaviors of the person depending on the tendency of violence. It has been determined that children who do not use violence are not adversely affected by red color stimulation and the psychological effect of red color causes positive associations on these children. At the same time, almost all of the children who did not use violence $(f=76)$ evaluate themselves with a positive psychology according to the children who stated that they were violent. This suggests that the connotations of red color influence the person's emotional reactions.

\section{Discussion and Conclusion}

It has been determined that red color can lead to negative emotional reactions in violent children, but that children without violence tendency are affected by positive psychology from red color stimulation. Therefore, it can be said that the reactions to the red color stimulus are influenced by the tendency of violence and that there is a direct relationship between the tendency of violence and tred color. It is thought that educators working with children should organize in-class activities related to different artistic methods and techniques in order to create color consciousness in children and to understand color-feeling relation. The psychological meanings of colors and the studies in which the psychological effect on emotions and behavior are supported by different artistic activities are thought to contribute positively to the development of the emotional and psychological development of the students and their ability to express themselves.

\section{Turkish Studies - Educational Sciences}

Volume 14 Issue 6, 2019 
Keywords: Red color, violence, conceptional and symbolic associations of red color.

\section{Giriş}

İnsan algısının önemli bir parçası olarak renk, günlük yaşamda tasarlanan birçok obje ya da nesnenin vermek istediği mesajı ifade etmek için kullanılmakta, kişiyi etkileyerek, farklı sosyal ve psikolojik tepkilere neden olmaktadır (Bagchi ve Cheema, 2013; Mohebbi, 2014; Olsen, 2010). Doğanın ve hayatımızın vazgeçilmez bileşeni olan renk, yaşamımıza anlam katan ya da çevremizle olan etkileşimimizi tamamlayan önemli bir görsel uyarıcı olarak tanımlanmaktadır (Mohebbi, 2014). Görsel uyarıcı olarak renkler aracılığı ile kişinin, nesne ya da varlıklara ilişkin dikkat süresinin arttığı, bilişsel becerilerinin geliştiği ve çevresini algılama biçiminin farklılaştığ vurgulanmaktadır (Jalil, Yunus ve Said, 2013). Yapılan araştırmalar renk algısının, bireylerin duygu ve davranışlarını etkilediği gerekçesiyle renklerin psikolojik olarak değerlendirilmesinin önemine vurgu yapmaktadır (DiRocco, 2012; Keskar, 2010; Singh, 2006; Valdez ve Mehrabian, 1994; Wiedemann, Burt, Hill ve Barton, 2015). Bu doğrultuda renk psikolojisinin genel modelinin altı temel prensibe dayandığ ifade edilmektedir (Elliot ve Maier, 2007; Whitfield ve Wiltshire, 1990). Bu prensiplerden birincisi rengin belirli bir anlam taşıması ile ilişkilendirilmektedir. Renk genel anlamda estetik bir değere sahip olsa da, sadece estetik amaçlar için kullanılırsa bu durumda psikolojik işleyiş üzerinde her hangi bir etkisi olmayacaktır. Dolayısıyla da her renk belirli bir anlam taşımakta, belirli mesajlar iletmekte ve insan psikolojisini kendiliğinden ya da farkında olmadan etkilemektedir (Elliot, Maier, Moller, Friedman ve Meinhardt, 2007; Olsen, 2010).

Renklerin anlamının hem öğrenilen ilişkiler hem de biyolojik tepkiler üzerine kurulu olduğu ifade edilmektedir (Olsen, 2010). Dolayısıyla da renklerin insan psikolojisi üzerindeki anlamları biyolojik ve şartlı öğrenme olmak üzere iki şekilde çağrışım yapmaktadır. Biyolojik olarak renklere verilen yerleşmiş tepkiler, gelişimsel açıdan faydalı tepkiler yoluyla gelişirken; şartlı öğrenme yoluyla renkler, birlikte ele alınan mesajlar, kavramlar, deneyim ya da fikirlerle ilişkilendirilmekte ve öğrenilen bu birlikteliğin bireyin davranışlarını etkilediği vurgulanmaktadır (Elliot ve Maier, 2007; Elliot ve Maier, 2012'den akt. Elliot, 2015). Üçüncü olarak, renk algısının bir uyaranın zararlı olup olmadığını belirlemek amacıyla değerlendirme süreçlerini çağrıştırdığı ifade edilmektedir. Diğer taraftan renk algısından kaynaklanan değerlendirme süreçlerinin, motive olmuş davranışları etkilediği ve olumlu ilişkiye sahip renklerin yaklaşım motivasyonunu, negatif ilişkiye sahip renklerin ise kaçınma motivasyonunu tetiklediği belirtilmektedir (Elliot \& Maier, 2007). Beşinci olarak değerlendirme sürecinin, rengin motive ettiği davranışı yapmaya zorladığı ve kişinin motivasyon davranışının harekete geçme ve işleyişine kadar olan tüm süreçlerinin bilinç ya da farkındalık olmaksızın gerçekleşmesi ile ilişkilendirilmektedir. Yani rengin etkisinin doğada bilinçsiz olma eğiliminde olması, rengin ortaya koyduğu etkinin zararlı olsa bile davranışı yerine getirme konusunda ısrarcı bir etkiye sahip olduğunu göstermektedir (Elliot \& Maier, 2007; Whitfield ve Wiltshire, 1990). Son olarak rengin anlamının ve etkisinin kişinin içinde bulunduğu duygu, düşünce ve davranışa ilişkin belirli şartlarla ilgili olduğu ifade edilmektedir. Örneğin bir başarı ortamında kırmızı renk, tehlike ve hatalarla ilişkilendirilirken; sosyal bir bağlamda kırmızı rengin romantizmle ilişkilendirilerek pozitif bir etki yaratabileceği ifade edilmektedir (Elliot \& Maier, 2007; Elliot \& Niesta, 2008; Whitfield ve Wiltshire, 1990).

Goldstein (1942'den akt. Elliot vd., 2007)'a göre kırmızı ve sarı, uyaran ya da hoşa gitmeyen renkler olarak insanları güçlü ve geniş kapsamlı davranışlar sergileme yönünde dışa dönük bir ortama odaklamaktadır. Yeşil ve mavi ise sessiz ve kabul edilebilir olarak deneyimlenmekte ve insanları iç dünyalarına yönlendirerek içine kapanık ya da kararlı davranışlar oluşmasına sebep olmaktadır. Mor renk, kişinin gerçekle sihirli bir ilişki kurma isteğini yansıtmaktadır. Kişi dünyasını büyülü ve sezgisel bir bütünlük haline getirmek için özne ile nesne 
ya da neden ve sonuç arasındaki farkı ortadan kaldırmak istemektedir (Luscher, 1991'den akt. Mohebbi, 2014). Siyahın ise çocukların geceleri karanlıktan korkması ve okudukları hikâyelerde siyahı kötülük ve canavarlarla ilişkilendirmeleri nedeniyle kötü ve ahlaksız kavramlar uyandırdığ ifade edilmektedir. Aksi beyaz için doğrudur (Gan, Fang ve Ge, 2016). Genel anlamda renkler insanlar üzerinde güzel duygular oluşturmak amacıyla kullanılmaktadır. Ancak insanların farklı renk uyaranlarından nasıl etkilendikleri kişiden kişiye değişkenlik göstermektedir (Abbasi, Talaei, Talaei ve Rezaei, 2014). Dolayısıyla da insanların başkalarıyla etkileşime girme biçimi, doğuştan gelen özelliklerine ve çocukluktan beri nasıl öğrendiklerine bağlı olarak birbirlerinden farklılaşmaktadır (Flanagan, 1999'dan akt. Wardono, Hibino ve Koyama, 2012). Çocukların zihinleri ve ruhları son derece yumuşak ve savunmasız olduğu için hayatlarındaki tüm bileşenler öğrendiklerini ve öğrenme şekillerini etkilemektedir. Çocuklar doğduklarından beri çevrelerindeki nesne ya da varlıklara tepki vermekte ve onlarla iletişim kurmaya çalışmaktadırlar. Parlak ve mutlu renklerin içindeki enerjisinden dolayı çocuklar koyu ve üzüntü veren renklerden ziyade açık ve mutlu renklere daha fazla eğilim göstermektedirler (Mohebbi, 2014).

Yapılan çalışmalar sarı ve mavi renklerin birey üzerindeki etkisiyle karşılaştırıldığında, kırmızı ve yeşilin etkilerinin daha anlamlı olduğu sonucuna ulaşmışlardır. Bu doğrultuda kırmızı rengin hem pozitif hem de negatif çağrışımlar uyandırdığı, diğer renkler içinde iradeyi ve güçlü duyguları temsil ettiği, hayati gücün bir ifadesi olduğu, kalp atış hızını, kan basıncını ve nefes almayı arttırdığı, sonuç ve başarı arzusunu temsil ettiği ifade edilmektedir (Luscher, 1991'den akt. Mohebbi, 2014; Moller, Elliot ve Maier, 2009'dan akt. Kuniecki, Pilarczyk ve Wichary, 2015). Diğer taraftan kırmızı rengin heyecan verici, uyarıcı; sıcaklık, daha az sakinlik; tehlike, tehdit ve uyarı işareti; öfke, saldırganlık ve baskınlık gibi kavramlarla ilişkili olduğu da vurgulanmaktadır (Edwards, Hamilton, Duntley ve Hubert, 1941'den akt. Shorenstein, 2016; Hill ve Barton, 2005; Meier, D'Agostino, Elliot, Maier ve Wilkowski, 2012; Oyama, 2003; Wexner, 1954'den akt. Buechner ve Maier, 2016; Wright ve Rainwater, 1962'den akt. Buechner ve Maier, 2016). Ayrica kırmızı rengin bireylere başarısızlık ve tehlike gibi kavramları hatırlatması nedeniyle kaçınma davranışına yol açtığı ifade edilmektedir (Gan, Fang ve Ge, 2016). Soldat, Sinclair ve Mark (1997'den akt. Elliot ve Maier, 2007) ise, kırmızı rengin mutluluğa bağlı olduğunu, bilişsel performansı zayıflatan sezgisel süreçleri çağrıştırdığını ve ilişkili olduğu duygularla tutarlı bilişsel işlemeye ve davranışa yol açtığını belirtmektedirler.

Kırmızı, insan psikolojisi ve davranışları üzerinde yüklendiği anlam ve uyandırdığ çağrışımlar nedeniyle diğer renklerden daha fazla tehdit edici ve baskın olarak algılanmaktadır (Wiedemann vd., 2015). Kanın rengini temsil etmesinden ötürü kırmızı rengin yaşam enerjisi verdiğine inanılmakta ve bu inanışın bir uzantısı olarak kırmızı renk savaşın, şiddetin ve kavganın da sembolü olarak görülmektedir (Küçükşen Öner, 2010). Bazı araştırmalar kırmızıya çok fazla maruz kalmanın şiddet içeren davranışları ve odaklanamamayı teşvik ettiğini ileri sürmektedirler (Abbasi vd., 2014; Bagchi ve Cheema, 2013; Hill ve Barton 2005; Little ve Hill 2007). Diğer taraftan Drummond ve Quah (2001), kişinin öfkelenmesi sonucu insan vücudundaki kan akışının artması ve ciltte kızarıklığa sebebiyet vermesi nedeniyle kırmızı rengin, öfke, düşmanlık ve tehlike gibi kavramların çağrışımına yol açtığını ifade etmektedirler. Ayrıca insanların ateşi, kanı ya da öfkeyi çağrıştırması ve bazı tehlikeli hayvanların rengi olması nedeniyle kırmızı rengi, negatif ya da tehlike taşıyan duygularla ilişkilendirmeye eğilimli oldukları belirtilmektedir (Moller, Elliot ve Maier, 2009'dan akt. Kuniecki, Pilarczyk ve Wichary, 2015). Dolayısıyla da yapılan çalışmalarda kırmızı rengin yerleşmiş biyolojik tepkiler üzerinden ya da öğrenilen mesajlar üzerinden ele alındığı görülmektedir. Bu araştırmada farklı olarak kırmızı rengin 11-12 yaş çocuklar üzerinde uyandırdığı kavramsal ve simgesel çağrışımlar, kişinin içinde bulunduğu şartlara göre sergilediği şiddet içeren davranışı açısından ele alınarak, kırmızı renk özelinde ortaya koyulmuştur. $\mathrm{Bu}$ doğrultuda araştırma, kırmızı rengin sahip olduğu geniş etki alanı nedeniyle, çocukların kırmızı rengin çağrışım yaptığı kavramları duygusal tepkileri ile ilişkilendirmek için kendilerini genel

\section{Turkish Studies - Educational Sciences}

Volume 14 Issue 6, 2019 
anlamda nasıl hissettikleri ve çevrelerindeki insanlara şiddet uygulayan ve şiddet uygulamayan çocuklar üzerinde, kırmızı rengin nasıl bir çağrışım uyandırdığı soruları üzerine yoğunlaşmaktadır.

\section{Yöntem}

\section{Araştırmanın Modeli}

Araştırma, karma yöntem araştırma desenlerinden yakınsayan paralel desen yaklaşımıyla yürütülmüştür. Yakınsayan paralel desen, nicel ve nitel verilerin birlikte toplanması, ayrı ayrı analiz edilmesi ve sonuçların birlikte yorumlanması olarak tanımlanmaktadır (Creswell ve Plano Clark, 2015). Bu doğrultuda araştırmada, renklerin bireyler üzerinde kavramsal ve simgesel olarak uyandırabileceği farklı çağrışımlar dikkate alındığında, görsel etkisi ve dikkat çekiciliği en yoğun olarak bilinen kırmızı rengin uyandırdığı farklı çağrışımların şiddet değişkeni üzerinden tespit edilmesi amaçlanmıştır.

\section{Çalışma Grubu}

Araştırmanın çalışma grubunu Karadeniz Bölgesinde yer alan bir ilde öğrenim gören ve amaçlı olarak seçilen 11-12 yaş aralığındaki toplam 147 ortaokul 7. sınıf öğrencisi oluşturmaktadır. Amaçlı örneklem, araştırma sorularının cevaplarıyla ilişkilendirilmiş belli amaçlara dayanarak bireyler seçme işlemi olarak tanımlanmaktadır (Teddlie ve $\mathrm{Yu}, 2007$ ). Bu doğrulta üniforma rengi olarak kırmızı rengin tercih edildiği bir devlet okulunun 11-12 yaş aralı̆̆ındaki 7. sınıf öğrencileri eğitim-öğretim ortamında kırmızı renge maruz kalmalarının bir gerekçesi olarak araştırmaya dâhil edilmiştir. 11-12 yaş aralığında çocuklar gelişim özelliklerine bağlı olarak bedensel ve psikolojik anlamda değişiklikler yaşamakta, çocuğun içinde bulunduğu sosyal çevre kişilik gelişiminde önemli bir rol oynamaktadır (Buyurgan ve Demirel, 2013). Ahlaki değerlerin oluşmaya başladığ 1 11-12 yaş aralığında çocuk, kendi davranışlarının sorumluluğunu üstlenme konusunda bilinçlenmekte, kişisel bağımsızlığını kazanmaya ve özel yetenek ve ilgilerini keşfetmeye başlamaktadır (EMPATİ, 2003). Bu düşünceden hareketle araştırmanın 11-12 yaş grubu çocuklar üzerinde yürütülmesi amaçlanmıştır.

Araştırmanın amacına yönelik olarak çalışma grubuna dâhil edilen 11-12 yaş grubu çocukların şiddet eğilimlerine göre demografik dağılımları Şekil 1'de sunulmuştur.

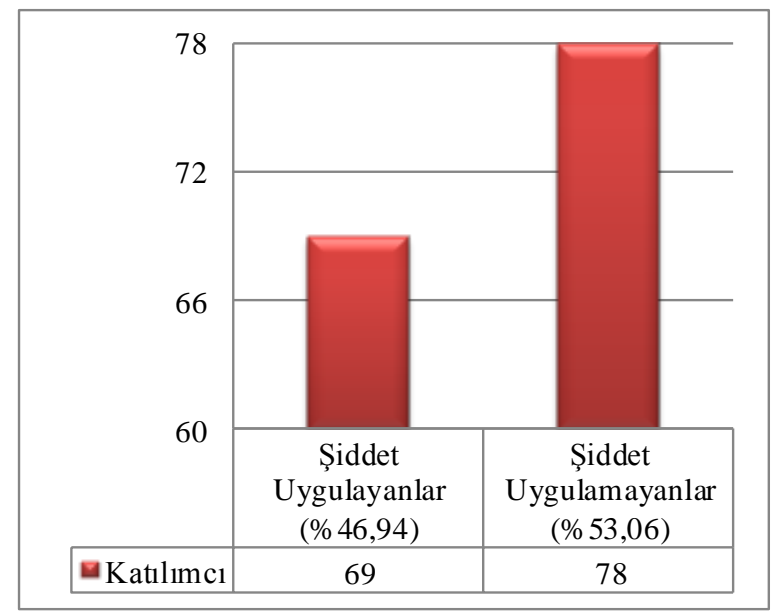

Şekil 1: Çocukların Şiddet Uygulama Düzeylerine Göre Dağılımları

Şekil 1'e göre kırmızı rengin 11-12 yaş çocuklar üzerinde uyandırdığ çağrışımlar çevresindeki insanlara şiddet uyguladığını ve şiddet uygulamadığını ifade eden çocuklar açısından iki aşamalı olarak değerlendirilmiştir. Bu doğrultuda araştırmaya katılan 11-12 yaş aralığındaki 
çocukların \%46,94'ünün ( $\mathrm{f}=69)$ çevresindeki insanlara "şiddet uyguladığı", \%53,06'sının ( $\mathrm{f}=78)$ ise çevresindeki insanlara "şiddet uygulamadı̆̆ı" tespit edilmiştir.

\section{Veri Toplama Araçları}

Kırmızı Rengin Kavramsal ve Simgesel Çağrışımları Ölçeği: Araştırma kapsamında, renk ve duygu ilişkisinin temelinde yer alan kavramsal ve simgesel çağrışımların rolünü kırmızı renk özelinde ortaya koymak amacıyla Küçükşen Öner (2010) tarafından geliştirilen, "kırmızı rengin kavramsal ve simgesel çağrışımları ölçeği”" kullanılmıştır. Öğrencilerin ölçekte yer alan maddelere verdikleri cevaplar "her zaman (5)", "sik sik (4)", "bazen (3)", "nadiren (2)", "hiç (1)" olacak şekilde 5'den 1'e doğru puanlandırılmıştır. Ölçeğin değerlendirilmesi, kırmızı rengi kavramsal ve simgesel algılayanlar için ayrı ayrı yapılmaktadır. Küçükşen Öner (2010) tarafindan geçerlik-güvenirlik çalışmaları yapılan ve dokuz (9) maddeden oluşan kırmızı rengin kavramsal çağrışımları alt ölçeğinin faktör yükleri ,440 ile ,709 değerleri arasında ve madde toplam puan korelasyonları ,613 ile ,737 değerleri arasında değişmektedir. Alt ölçeğin Cronbach Alfa güvenirlik katsayısı ise ,775 olarak hesaplanmıştır. Ölçekte yer alan ve yedi (7) maddeden oluşan kırmızı rengin simgesel çağrışımları alt ölçeğinin faktör yükleri ,306 ile ,581 değerleri arasında ve madde toplam kolerasyonları ,611 ile ,787 değerleri arasında değişmektedir. Alt ölçeğin Cronbach Alfa güvenirlik katsayısı ise ,793 olarak hesaplanmıştır. Elde edilen bu bulgular kırmızı rengin kavramsal ve simgesel çağrışımları ölçeğinin geçerli ve güvenilir bir ölçek olduğunu göstermektedir.

Kırmızı Rengin Kavramsal ve Simgesel Çağrışımları Anket Formu: Araştırmada 11-12 yaş çocuklarda şiddet değişkenine göre kırmızı rengin kavramsal ve simgesel çağrışımlarını tespit etmek amaciyla yine Küçükşsen Öner (2010) tarafindan geliştirilen kişisel bilgiler formundan derleme yapılarak "kırmızı rengin kavramsal ve simgesel çağrışımları anket formu" geliştirilmiştir. Anket formu iki aşamadan oluşmaktadır. Birinci aşamada öğrencilere yaş düzeyleri ve şiddet eğilimlerine ilişkin kişisel bilgileri sorulmuştur. İkinci aşamada ise öğrencilere, kırmızı rengin kavramsal ve simgesel çağrışımlarını öğrencilerin psikolojik gelişimleri üzerindeki etkisini de dikkate alarak tespit etmek amacıyla iki adet soru yöneltilmiştir. Yöneltilen sorular kapsamında kırmızı rengin çağrışım yaptı̆̆ 1 kavramları öğrencilerin duygusal tepkileri ile ilişkilendirmek amaciyla öğrencilere kendilerini duygusal anlamda nasıl hissettikleri sorulmuştur. Anket formu kapsamında öğrencilere yorumlamaya dayalı açık uçlu bir soru sorularak kırmızı rengin öğrenciler üzerinde nasıl bir çağrışım uyandırdığını gerekçeleri ile birlikte açıklamaları istenmiştir. Ölçek ve anket formunun uygulanması sonucunda 153 kişiden veri toplanmıştır. Ancak ulaşılan anketlerin 6 tanesi sorulardan bazılarının boş bırakılması nedeniyle elenerek, 147 anket araştırmaya dâhil edilmiştir.

\section{Verilerin Analizi}

\section{Nicel Verilerin Analizi}

Nicel verilerin analizi aşamasında, verilerin normal dağılım özelliği gösterip göstermediğine çarpıklık ve basıklık değerlerine bakılarak karar verilmiştir. Verilerin normal dağılım özelliği gösterdiğine karar vermek için çarpıklık ve basıklık katsayılarının " \pm 1 ” aralığında olmas1 gerektiği vurgulanmaktadır (Morgan vd., 2004, s.49'dan aktaran: Can, 2014). Ölçek puanlarına ilişkin betimsel istatistik değerleri Tablo 1'de sunulmuştur.

Tablo 1: Ölçüm Puanlarına Ait Betimsel İstatistik Değerleri

\begin{tabular}{lccccc}
\hline Ölçüm & $\mathrm{N}$ & $\overline{\mathrm{X}}$ & $\mathrm{S} . S$. & Çarpıklık & Basıklık \\
\hline Kavramsal & 147 & 2,59 &, 593 &, 157 &, 760 \\
Simgesel & 147 & 3,05 &, 701 &,- 205 &,- 100 \\
\hline
\end{tabular}


Tablo 1 incelendiğinde ölçek alt faktörleri için çarpıklık ve basıklık katsayılarının \pm 1 aralığında olduğu görülmektedir. Ölçek puanlarının normal dağılım göstermesi nedeniyle nicel verilerin analizinde $t$ testi kullanılmıştır. Ölçekten alınan puanlar ise, Tablo 2'de verilen puan aralıkları dikkate alınarak yorumlanmıştır.

Tablo 2: Ölçek Puan Aralığı

\begin{tabular}{lcc}
\hline Derecelendirme & Puan & Puan Aralı̆̆ 1 \\
\hline Her Zaman & 5 & $4,20-5,00$ \\
Sık Sık & 4 & $3,40-4,19$ \\
Bazen & 3 & $2,60-3,39$ \\
Nadiren & 2 & $1,80-2,59$ \\
Hiç & 1 & $1,00-1,79$ \\
\hline
\end{tabular}

Tablo 2'ye göre kırmızı rengin kavramsal ve simgesel çağrışımları ölçeğinden alınan puanlar 5'den 1'e doğru kodlanarak yorumlanmıştır.

\section{Nitel Verilerin Analizi}

Nitel verilerin analizi aşamasında şiddet değişkenine göre kırmızı rengin 11-12 yaş çocuklar üzerindeki kavramsal ve simgesel çağrışımları "(1) betimleme, (2) sınıflandırma ve (3) ilişkilendirme" olmak üzere Dey'in (1993) üç aşamalı modeline göre analiz edilmiştir. Betimleme aşaması kişi, nesne ve olayların temel özelliklerinin kapsamlı olarak tanımlanması ve içeriğin açıklanması aşamalarını içermektedir. Sınıflandırma aşamasında veri setinde yer alan değişkenler arasındaki ilişkileri ve farklılıkları inceleyip karşılaştırma yapabilmek amacıyla toplanan veriler kodlanarak çözümlenir ve belirli temalar altında sınıflandırılır. İlişkilendirme aşamasında ise araştırmacı, elde ettiği temaları birbirleriyle ilişkilendirerek, değişkenler arasında bağlantı kurmaya çalışır (Dey, 1993'den akt, Özdemir, 2010; Pekdoğan, 2018). Yapılan araştırmada 11-12 yaş grubu çocukların kırmızı rengin kavramsal ve simgesel çağrışımları anket formuna verdikleri cevaplar yazılı bir metne dönüştürülerek, kapsamlı olarak tanımlanmış ve veri seti elde edilen bulgular 1şığında benzer özellikleri dikkate alınarak sınıflandırılmıştır. Yapılan sınıflandırmada çocukların çevrelerindeki insanlara şiddet uygulayıp uygulamadıkları dikkate alınarak şiddet değişkenine göre kırmızı rengin nasıl bir çağrışım uyandırdığına ilişkin kodlama yapılmış ve bu kodlamalar öğrenci görüşleri doğrultusunda tanımlanan çağrışımlara göre sınıflandırılmıştır. Veri setinde ortak özellikleri bakımından tanımlanan çağrışımları temsil ettiği düşünülen farklı kategoriler oluşturulmuştur. Analizin son aşamasında belirlenen kategoriler, çevresindeki insanlara şiddet uyguladığını belirten öğrenciler için "olumsuz kavramsal çağrışımlar", "olumlu kavramsal çağrışımlar" ve "manevi simgesel çağrışımlar" olmak üzere üç kategori altında birleştirilirken; şiddet uygulamadığını ifade eden çocuklar için "olumlu kavramsal çağrışımlar" ve "manevi simgesel çağrışımlar" olmak üzere iki kategori ile ilişkilendirilmiştir. Araştırmanın güvenirliğini sağlamak amaciyla bir sanat eğitimi alan uzmanının görüşlerine başvurulmuş ve elde edilen çağrışımların belirlenen kategorileri temsil etme düzeyi incelenmiştir. Bu doğrultuda alan uzmanına kategori ve çağrışımların yer aldığı iki farklı liste verilerek, ilgili çağrışımları temsil ettiğini düşündüğü kategorilere yerleştirmesi istenmiştir. Uzmanın yaptığ 1 eşleştirmeler ile araştırmacının yaptığ eşleştirmeler karşılaştırılarak, yapılan analizlerin güvenirliği Miles ve Huberman (1994, s.64) tarafindan kuramsallaştırılan "güvenirlik = görüş birliği / (görüş birliği + görüş ayrılığı) X 100" formülü kullanılarak hesaplanmıştır. Uzman tarafindan iki çağrışım (aşk, özgürlük) araştırmacının yaptığı kodlamadan farklı bir kategoriyle ilişkilendirilmiş ve güvenirlik \%96 olarak hesaplanmıştır. Miles ve Huberman (1994, s.64) güvenirlik oranın \%70 ve üzerinde olmasının yeterli olacağını belirtmektedir. Güvenirliğin sağlanmasından sonra araştırmaya katılan çocuklardan şiddet uygulamadığını ifade eden 78 kişi A1...A78 ve şiddet uyguladığını ifade eden 69 kişi B1...B69 aralığında kodlanarak, ilgili kategoriler altında birleştirilen çağrışımlara ilişkin benzerlikler ve farklılıklar katılımcıların görüşlerinden derlenen örnek açıklamalarla desteklenerek yorumlanmıştır. Veriler frekans (f) değerleri verilerek sunulmuştur. 


\section{Bulgular}

\section{Araştırmanın Nicel Boyutundan Elde Edilen Bulgular}

Araştırmada 11-12 yaş çocuklarda kırmızı rengin kavramsal ve simgesel çağrışımlarını şiddet değişkeni üzerinden belirlemek amacıyla ölçekten alınan puanlar karşılaştırılmıştır. Ölçeğe ilişkin betimsel istatistik değerleri Tablo 3'de verilmiştir.

Tablo 3: Öğrencilerin Şiddet Değişkenine Göre Ölçek Puanlarının t Testi Sonuçları

\begin{tabular}{llllllll}
\hline Değişken & Grup & $\mathrm{N}$ & $\overline{\mathrm{X}}$ & $\mathrm{Ss}$ & $\mathrm{sd}$ & $\mathrm{t}$ & $\mathrm{p}$ \\
\hline \multirow{2}{*}{ Kavramsal } & Şiddet Uygulayan & 69 & 2.83 & .546 & \multirow{2}{*}{145} & \multirow{2}{*}{4.889} & \multirow{2}{*}{$.000^{*}$} \\
& Şiddet Uygulamayan & 78 & 2.38 & .557 & & & \multirow{2}{*}{.348} \\
\hline \multirow{2}{*}{ Simgesel } & Şiddet Uygulayan & 69 & 2.99 & .692 & \multirow{2}{*}{145} & \multirow{2}{*}{-.941} & \\
& Şiddet Uygulamayan & 78 & 3.10 & .708 & & &
\end{tabular}

Tablo 3'te kırmızı rengin kavramsal ve simgesel çağrışımları ölçeğinin alt ölçeklerine ilişkin $t$ testi sonuçları gösterilmiştir. Buna göre kırmızı rengin kavramsal çağrışımları alt ölçeği incelendiğinde, şiddet uyguladığını ifade eden 11-12 yaş çocukların puanlarının "bazen" ( $\overline{\mathrm{X}}_{\text {(Ș. }}$ UYGL.) $=2,83$ ), şiddet uygulamadığını ifade eden 11-12 yaş çocukların puanlarının ise, "nadiren" ( $\bar{X}$ (S. UYGM.) $=2,38)$ şeklinde gerçekleştiği görülmektedir. Bu sonuca göre, 11-12 yaş çocukların "kavramsal çağrışımlar" alt ölçeğine ilişkin puanlarının, şiddet değişkenine bağlı olarak farklılaştığı ve bu farklılaşmanın da istatistiksel olarak $\mathrm{p}<.001$ düzeyinde anlamlı olduğu görülmektedir. "Kırmızı renk tehlikeyi çağrıştırır", "kırmızı renk kavga ve şiddeti hatırlatır", "gökyüzü renginin kırmızıya (kızıla) dönmesi kötü şeylerin olacağını düşündürür" ya da "kırmızı renkli bir kıyafet giydiğimizde kendimizi daha güçlü hissederiz" şeklinde ifadelerin yer aldığı kavramsal çağrışım alt ölçeği, kırmızı rengin zihindeki soyut anlamını ölçmeyi hedeflemektedir. $\mathrm{Bu}$ doğrultuda elde edilen veriler şiddet uyguladığını ifade eden çocukların şiddet uygulamadığını ifade eden çocuklara göre kırmızı rengi, belirli mesajlar, kavramlar, deneyim ya da fikirler üzerinden değerlendirdiklerini göstermektedir.

Kırmızı rengin simgesel çağrışımları alt ölçeği incelendiğinde, şiddet uyguladığını ve şiddet uygulamadığını ifade eden 11-12 yaş çocukların puanlarının "bazen" $\left(\overline{\mathrm{X}}_{\text {(S. UYGL.) }}=2,99 ; \overline{\mathrm{X}}_{\text {(S. }}\right.$. UYGM.) $=3,10$ ) puan aralığında yer aldığ 1 görülmektedir. Bu sonuca göre, 11-12 yaş çocukların "simgesel çağrışımlar" alt ölçeğine ilişkin puanlarının, şiddet değişkenine bağlı olarak farklılaşmadığı ve istatistiksel olarak anlamlı olmadığı görülmektedir. "Uğur böceğinin uğur getirmesinin sebebi renginin kırmızı olmasıdır", "resimlerimizde kırmızı kalp çizdiğimizde sevgi, mutluluk, aşk gibi duyguları anlatmak isteriz" ya da "bayrağımızın milli duygularımızı coşturmasının sebebi, kırmızı renkte olmasıdır" şeklinde ifadelerin yer aldığı simgesel çağrışım alt ölçeği, kırmızı rengin duyularla ifade edilemeyen anlamını ölçmeyi hedeflemektedir. $\mathrm{Bu}$ doğrultuda elde edilen veriler şiddet uyguladığını ve şiddet uygulamadığını ifade eden çocukların kırmızı rengi duyusal olarak aynı sembollerle değerlendirdiklerini göstermektedir.

\section{Araştırmanın Nitel Boyutundan Elde Edilen Bulgular}

Araştırmada şiddet değişkenine göre kırmızı rengin 11-12 yaş çocuklar üzerinde çağrışım yaptığı kavramaları belirlemek amacıyla kullanılan kırmızı rengin kavramsal ve simgesel çağrışımları anket formu nitel araştırma yaklaşımı doğrultusunda analiz edilmiştir. Bu anket doğrultusunda çocukların kırmızı rengin çağrışım yaptı̆̆ı kavramları duygusal tepkileri ile ilişkilendirmek için kendilerini genel anlamda nasıl hissettikleri ve kırmızı rengin nasıl bir çağrışım uyandırdığını gerekçeleri ile birlikte açıklamaları istenmiştir. Elde edilen bulgular çevrelerindeki insanlara şiddet uyguladığını ve şiddet uygulamadığını ifade eden çocuklar açısından şiddet değişkeni dikkate alınarak iki aşamalı olarak değerlendirilmiştir. 
Şiddet değişkeni bağlamında çocukların genel olarak kendilerini nasıl hissettiklerine ilişkin duygusal tepkileri Şekil 2'de sunulmuştur.

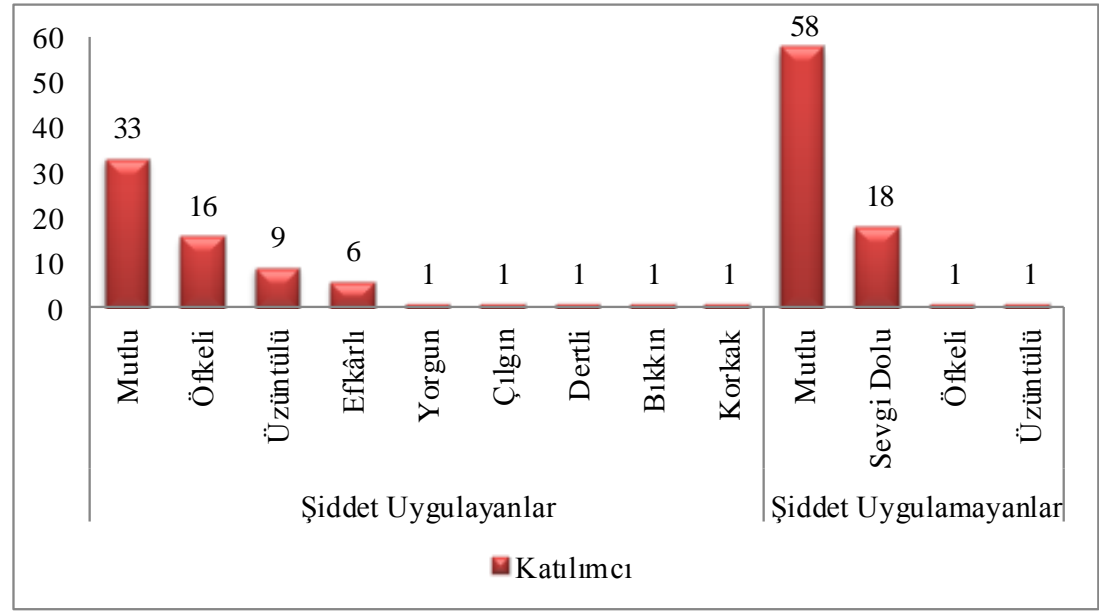

Şekil 2: Çocukların Duygusal Tepkilerine Göre Dağılımları

Şekil 2'ye göre şiddet uyguladığını ( $\mathrm{f}=33$ ) ve şiddet uygulamadığını $(\mathrm{f}=58)$ ifade eden çocukların büyük bir çoğunluğu duygusal tepkileri açısından kendilerini "mutlu" olarak tanımlamaktadırlar. Diğer taraftan şiddet uygulamadığını ifade eden çocukların kendilerini mutluluk dışında sevgi dolu ( $\mathrm{f}=18)$ hissettiklerine ilişkin görüş belirttikleri ancak sadece iki öğrencinin öfkeli ve üzüntülü hissettiği şeklinde duygusal tepkilere yer verdikleri görülmektedir. Şiddet uyguladığını ifade eden çocukların ise büyük bir çoğunluğunun kendilerini, duygusal tepkileri açısından "öfkeli ( $\mathrm{f}=16)$ ", “üzüntülü ( $\mathrm{f}=9)$ " ve "efkârlı (6)" olarak tanımladıkları görülmektedir. Elde edilen bulgular ş̧ı̆̆ında şiddet uyguladığını ifade eden çocukların bir kısmının kendilerini genel anlamda mutlu olarak değerlendirmelerine karşın; diğer kısmının ise şiddet uygulamadığını ifade eden çocuklara göre kendilerini olumsuz bir psikoloji ile değerlendirdikleri anlaşılmaktadır. $\mathrm{Bu}$ doğrultuda rengin anlamının ve etkisinin kişinin içinde bulunduğu duygu, düşünce ve davranışa ilişkin belirli şartlarla ilgili olduğu (Elliot \& Maier, 2007; Elliot \& Niesta, 2008; Whitfield ve Wiltshire, 1990) düşüncesinden hareketle araştırmada, şiddet uyguladığını ve şiddet uygulamadığını ifade eden çocuklar üzerinde kırmızı rengin nasıl bir çağrışım uyandırdığı sorusuna cevap aranmıştır. Şiddet değişkeni dikkate alınarak kırmızı rengin 11-12 yaş çocuklar üzerinde çağrışım yaptığı kavramlara ilişkin öğrenci görüşleri doğrultusunda oluşturulan kırmızı rengin çağrışımları ve bu çağrışımların ilişkili olduğu kategoriler Tablo 4'de sunulmuştur. 
Tablo 4: Şiddet Değişkenine Göre 11-12 Yaş Çocuklarda Kırmızı Rengin Kavramsal ve Simgesel Çağrışımları

\begin{tabular}{|c|c|}
\hline Şiddet Uygulayanlar & Şiddet Uygulamayanlar \\
\hline Olumsuz Kavramsal Çağrıșımlar $(\mathbf{f}=84)$ & Olumlu Kavramsal Çağrışımlar $(\mathbf{f}=93)$ \\
\hline - $\quad \operatorname{Kan}(14)$ & \\
\hline - Öfke (11) & - Mutluluk (2l) \\
\hline - $\quad$ Cinayet (9) & - Özgürlük (14) \\
\hline - S Siddet (7) & - Aşk (10) \\
\hline $\begin{array}{ll}- & \text { Ateş (6) } \\
- & \text { Tehlike (6) }\end{array}$ & - Canlılık (4) \\
\hline $\begin{array}{l}\text { - Tehlike (6) } \\
\text { - Kavga (4) }\end{array}$ & - $\quad$ Asillik (2) \\
\hline $\begin{array}{ll}- & \text { Kavga (4) } \\
\text { - } & \text { Kötülük (4) }\end{array}$ & - $\quad$ Güçlü Olma (2) \\
\hline - Vahşet (4) & $\begin{array}{l}-\quad \text { Güzellik (2) } \\
\bullet \quad \text { Huzur (2) }\end{array}$ \\
\hline - $\quad$ Ölüm (3) & - Heşe (2) \\
\hline - Savaş (3) & - Sicaklik(2) \\
\hline $\begin{array}{ll}- & A c l(2) \\
- & K l z g l n l ı k(2)\end{array}$ & - Başarı (1) \\
\hline - Korku (2) & - Cana Yakınlık (1) \\
\hline - Bıkkınlık (1) & - Cazibe (1) \\
\hline - Boğuculuk (1) & - Carpicilik (1) \\
\hline - Cehennem (1) & - Enerji (1) \\
\hline - Intikam (I) & - Özgüven (1) \\
\hline $\begin{array}{l}-\quad \text { Nefret (1) } \\
\text { - Sevtanllk (1) }\end{array}$ & - Rahatllk (1) \\
\hline - Utanma (1) & - $\quad$ Sakinlik (1) \\
\hline Olumlu Kavramsal Çağrışımlar $(\mathrm{f}=15)$ & \multirow{2}{*}{ Manevi Simgesel Çă̆rışımlar $(\mathbf{f}=40)$} \\
\hline - $\quad A s ̧ k(8)$ & \\
\hline - $\quad$ Kalp (2) & \multirow{11}{*}{ 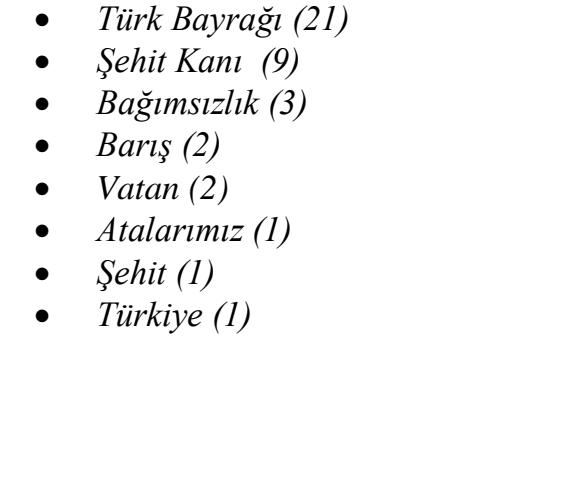 } \\
\hline - Adalet (1) & \\
\hline - $\quad \operatorname{Asillik}(1)$ & \\
\hline - Cesaret (1) & \\
\hline - Güçlü Olma (1) & \\
\hline - Mutluluk (1) & \\
\hline Manevi Simgesel Çağrışımlar $(\mathbf{f}=\mathbf{3 1})$ & \\
\hline - Türk Bayrağı (20) & \\
\hline - S Sehit Kanı (8) & \\
\hline - Sehit (2) & \\
\hline - Bağımsizlık (1) & \\
\hline
\end{tabular}

Tablo 4'e göre 11-12 yaş çocukların kırmızı rengin kavramsal ve simgesel çağrışımları anket formuna verdikleri cevaplar, şiddet uyguladığını ifade eden çocuklar için "olumsuz kavramsal çağrışımlar", "olumlu kavramsal çağrışımlar" ve "manevi simgesel çağrışımlar" olmak üzere üç kategoride toplanmıştır. Şiddet uygulamadığını ifade eden çocukların çağrışımları ise, olumlu kavramsal çağrışımlar" ve "manevi simgesel çağrışımlar" olmak üzere iki kategoride toplanmıştır. Elde edilen bulgular kırmızı rengin çağrışımlarının 11-12 yaş çocuklar üzerinde şiddet değişkeni açısından farklılaştığını göstermektedir. $\mathrm{Bu}$ farklılaşmaya göre şiddet uyguladığını belirten çocuklar kırmızı rengi kan ( $f=14)$, öfke $(f=11)$, cinayet $(f=9)$, şiddet $(f=7)$, tehlike $(f=6)$ ve kavga ( $\mathrm{f}=4)$ gibi olumsuz kavramlarla ilişkilendirirken; şiddet uygulamadığını belirten çocuklar ise kırmızı rengi sevgi ( $\mathrm{f}=23)$, mutluluk $(\mathrm{f}=21)$, özgürlük $(\mathrm{f}=14)$ ve aşk $(\mathrm{f}=10)$ gibi olumlu kavramlarla ilişkilendirmektedirler. Şiddet uyguladığını ifade eden 11-12 yaş grubu çocuklar kırmızı rengin çă̆rışım yaptığı kavramlara ilişkin gerekçelerini şu şekilde ifade etmektedirler: 
- "Kırmızı ateş, korku ve cehennemin rengidir. Ateş benim en sevdiğim elementtir. Korkutucudur ve bana şiddeti çağrıştırır" (B5).

- "Kırmızı denince aklıma kan gelir çünkü kan damarlarımızda akar ve kavga edince bir yerlerimiz kanar" (B6).

- "Kırmızı ateşin rengidir. Ateş kırmızıdır ve kötülügüu simgeler" (B14).

- "Kırmızl şiddetin rengidir çünkü macera ve korkuyu severim" (B18).

- "Bir yerimiz kesilince kan akar ve çok acı çekebiliriz. Acı çektiğimiz için kırmızı renk kötülügün ve acinin sembolüdür”(B20).

- "Kırmızı renk öfke, ölüm ve şiddetin rengidir. Çünkü bir insan birisine ya da ailesine silah ve bıçak ile saldırabilir. Silah ile vurulduğumuzda kan akar ve ölürüz. Ben kırmızı renkten bunu anllyorum" (B35).

- "Kırmızı renk şiddettir. Bana kadınlara yapılan şiddeti ve cinayetleri hatırlatır" (B44).

- "Kırmızı öfkenin rengidir. Çünkü bana göre en güçlü duygu öfke aynı zamanda en güçlü renk de kırmızıdır" (B53).

- "Kırmızı öfkeyi çağrıştırıyor. Çünkü alev alev bir renk olduğu için sinirli bir renk gibi geliyor bana" (B59).

- "Kırmızı renk tehlikeyi çağrıştırır. Genelde filmlerde tehlike için kullanılır. Nerde kirmızı görsem tehlike olduğunu anlarım" (B62).

Şiddet uygulamadığını ifade eden 11-12 yaş grubu çocuklar ise, kırmızı rengin çağrışım yaptığı kavramlara ilişkin gerekçelerini şu şekilde ifade etmektedirler:

- "Kırmızı çok güzel bir renk bu yüzden bana mutluluk katıyor" (A4).

- "Kırmızı sicaklığ ifade eder çünkü insanlara hoş ve sicak gelir. Sebebi kırmızının göze

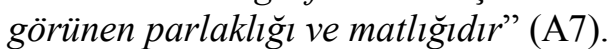

- "Kırmızı aşkın rengidir çünkü insanları birbirine daha iyi bağlar" (A13).

- "Kırmızı içimizi coşturan asil bir renktir, bazen mutluluk bazen aşktır. Mutlu olunca aşkta olur" (A21).

- "Mutluluğumuzu anlatmak için kırmızı kullanırız. Kalbimizde kelebekler uçuşurken onu temsil eden renk kırmızıdır" (A26).

- "Kırmızı canlıllk ifade eder çünkü göz alıcl, canlı bir renk" (A34).

- "Kırmızı en sevdiğim renk ve insanın içinde huzur, mutluluk ve sevgi hissettirir" (A36).

- "Genellikle resimlerde sevgi ve mutluluğu ifade ederken kırmızı kullanırız" (A42).

- "Sevgiyi, aşkı ve mutluluğu hep kırmızıyla ifade ediyoruz. Sevgi dolu şeyler hep kırmızı renk ile yapıllyor. Kırmızı bana hayat veriyor ve aşkın simgesini anlatıyor" (A51).

- "Kırmızı özgürlüğ̈̈ çăgrıştırır. Kırmızı renk özgür ve güçlü olduğumuzun göstergesidir" (A67).

Tablo 4'e göre, kırmızı rengin 11-12 yaş çocuklar üzerinde benzer özellikleri bakımında çağrışım yaptığı kavramlar "manevi simgesel çağrışımlar" ve "olumlu kavramsal çağrışımlar" olmak üzere iki ortak kategori altında toplanmıştır. Manevi simgesel çağrışımlar kategorisinde çocukların kırmızı rengi, Türk Bayrağını ve Vatan uğruna dökülen kanları temsil ettiği gerekçesiyle Türk Bayrağı, şehit kanı, şehit ve bağımsızlık gibi kavramlarla ilişkilendirdikleri görülmektedir. Diğer taraftan şiddet uyguladığını ifade eden çocukların genel olarak kırmızı rengi olumsuz kavramlarla ilişkilendirseler de aşk $(\mathrm{f}=8)$, kalp $(\mathrm{f}=2)$, adalet $(\mathrm{f}=1)$, asillik $(\mathrm{f}=1)$ ve mutluluk $(\mathrm{f}=1)$ gibi kavramlara atıfta bulunarak, kırmızı rengin olumlu etkisi $(\mathrm{f}=15)$ açısından şiddet uygulamadığını ifade eden çocuklarla ortak görüş belirttikleri de görülmektedir. Bu doğrultuda katılımcılar görüşlerini şu şekilde ifade etmektedirler:

- “Kırmızı Türk Bayrağımızı ifade ediyor. Bu Ülke de barış ve kardeşlik ile yaşamalıyız. Kırmızı rengi akan kan değil, Türk Bayrağımızın rengi olmalı" (A2). 
- "Kırmızı vatanını, milletini koruyan, yüceltmeye çalışan şehitlerimizin dökülen kanlarıdır. Ben Vatanımı, milletimi seviyorum. Ben de büyüyünce ya şehit olacağım ya da dökülen kanlarımız için mücadele edeceğim" (A5).

- "Kırmızı renk benim için bayrağımızdaki şehitlerimizin kanını ifade ediyor. Benim atalarım o al bayrak ugruna canlarını verdiler ve onların kanlarıyla o ay yıldızlı bayrak renk buldu" (A10).

- "Kırmızı renk Atalarımızın korkmadan savaştı̆̆l, şehit olduğu kanlarımızın anlamıdır. Vatan çok kolay kazanılmadı ve bizden başka kimse vatan toprağına ayak basamaz" (B10).

- "Kırmızı şehitlerimizin kanının rengidir. O kadar dökülen kanlar ve savaşların nedenidir" (B24).

- "Kırmızı bayrağımızın rengidir. Atalarımız bu bayrak ve bizim için çok savaş yaptı. Şehitlerimizin uğruna savaştığı renktir" (B34).

\section{Tartışma, Sonuç ve Öneriler}

Araştırma sonuçları çevresindeki insanlara şiddet uyguladığını ve şiddet uygulamadığını ifade eden 11-12 yaş çocukların renk uyaranlarına kavramsal olarak verdikleri tepkilerde kendi yaşantıları yoluyla edindikleri deneyimlerinin şiddet değişkeni ile bağlantılı olarak farklı çağrışımlara neden olduğu; ancak simgesel olarak verilen tepkilerde ise herhangi bir farklılaşma olmadığı sonucunu ortaya koymaktadır. Bu doğrultuda araştırmanın nicel ve nitel boyutundan elde edilen bulguların da birbirlerini desteklediği görülmektedir. Araştırmanın nicel boyutundan elde edilen veriler şiddet uyguladığını ifade eden çocukların şiddet uygulamadığını ifade eden çocuklara göre kırmızı rengi kavramsal açıdan belirli mesajlar, kavramlar, deneyim ya da fikirler üzerinden değerlendirirken; simgesel açıdan her iki grup arasında her hangi bir farklılaşmanın olmadığını göstermektedir. Araştırmanın nitel boyutundan elde edilen bulgularda şiddet uyguladığını ifade eden çocukların kırmızı rengi kavramsal açıdan kan, öfke, cinayet gibi çağrışımlarla ilişkilendirmelerine karşın; şiddet uygulamadığını ifade eden çocukların aşk, mutluluk gibi olumlu kavramlar üzerinden değerlendirme yapmaları ve simgesel çağrışımlarında ise her iki grup arasında Türk Bayrağı, şehit kanı gibi manevi duyguları temsil eden sembollere ortak görüş belirterek yer vermeleri bakımından araştırmanın nicel boyutunu doğrulamaktadır. Diğer taraftan, şiddet uyguladığını ifade eden çocukların bir kısmının, şiddet uygulamadığını ifade eden çocuklara göre kendilerini olumsuz bir psikoloji ile değerlendirmeleri kırmızı rengin çağrışım yaptığı kavramların günlük hayatta yaşanan olumsuz duygusal tepkilerden de etkilenebileceği sonucuna işaret etmektedir. Bu doğrultuda araştırma sonuçları kırmızı rengin anlamının ve etkisinin kişinin şiddet eğilimine bağlı olarak içinde bulunduğu duygu, düşünce ve davranışlardan etkilendiğini göstermektedir. Dolayısıyla da kırmızı renk uyaranına verilen tepkilerin şiddet eğiliminden etkilendiği ve şiddet eğilimi ile kırmızı rengin kavramsal ve simgesel çağrışımları arasında doğrudan bir ilişki olduğu söylenebilir.

Alanyazın incelendiğinde, Pellegrini, Schauss ve Miller (1981) okul öncesi çocuklar üzerinde yaptıkları araştırmalarında pembe rengin çocukların fiziksel yeterliğini ve ruh halini olumlu yönde etkilediği sonucuna ulaşmışlardır. Ancak pembe renge boyanan bir cezaevi odasında pembe renk, mahkûmun ruh halini olumsuz etkilemiş ve saldırgan davranışların ortaya çıkmasına neden olmuştur. Wiedemann vd., (2015) araştırmalarında katılımcılara, kırmızı, mavi ve gri renkte gömlek giyen 20 farklı kişinin görüntüsünü izleterek, kırmızı renkli giysilerin rekabet ortamları dışında saldırganlık ve baskınlık algısını ne ölçüde etkilediğini tespit etmeye çalışmışlardır. Araştırma sonuçları kırmızı renk kıyafet giyen bireylerin mavi ve gri renk kıyafet giyen bireylere göre anlamlı şekilde daha öfkeli olarak sınıflandırıldığını ve kırmızı rengin insanlarda baskınlık ve saldırganlık eğilimini tahmin etmek amacıyla bir işaret olarak kullanılabileceğini göstermiştir. $\mathrm{Bu}$ doğrultuda kırmızı rengin, bir uyaranın dikkat çekici olduğu bilgisini taşıyan önemli bir uyarı sinyali olduğu ifade edilmektedir (Buechner, Maier, Lichtenfeld ve Elliot, 2014'den akt. Buechner

\section{Turkish Studies - Educational Sciences}

Volume 14 Issue 6, 2019 
ve Maier, 2016). Gueguen, Jacob, Lourel ve Pascual (2012) ise çalışmalarında, kırmızı 1şıkta bekleyen 422 katılımcının trafik ışığı yeşile döndüğünde, eğer karşı taraftaki sürücü kırmızı renkli bir araba kullanıyorsa ve trafiği işgal etmişse diğer renk arabalara göre, daha hızlı ve daha saldırgan bir şekilde tepki verdikleri sonucuna ulaşmışlardır. Yapılan çalışmaların kişinin renk uyaranlarına verdikleri tepkilerde kendi yaşantıları yoluyla edindiği deneyimlerinin şiddet eğilimi ile bağlantılı olarak duygu ve davranışlarında farklılaşmaya neden olabileceği gerekçesiyle araştırma sonuçlarıyla örtüştüğü görülmektedir.

Araştırma sonuçları şiddet uygulamadığını ifade eden çocukların kırmızı renk uyaranından olumsuz olarak etkilenmediklerini aksine, kırmızı rengin bu çocuklar üzerinde olumlu çağrışımlar uyandırdığını göstermektedir. Aynı zamanda şiddet uygulamadığını ifade eden çocukların hemen hemen hepsinin, şiddet uyguladığını ifade eden çocuklara göre kırmızı rengi olumlu çağrışımlarla değerlendirmeleri kırmızı rengin çağrışım yaptı̆̆ kavramların kişinin duygusal tepkilerinden etkilendiği sonucuna işaret etmektedir. Kırmızı rengin saldırgan, sinirli ya da öfkeli gibi olumsuz anlamlarının yanı sıra aktif, güçlü ve tutkulu gibi olumlu anlamlarının olduğu da belirtilmektedir (Kaya ve Epps, 2004). Bu doğrultuda Hill ve Barton (2005) yaptıkları çalışmada, sporcuların kıyafetlerindeki renklerin spor müsabakalarında elde edilen sonuçlarla olan bağlantısını araştırmışlardır. Kırmızı spor kıyafetleri giyen boks, tekvando ve güreş sporcularının diğer renklerde spor kıyafeti giyen rakiplerinden daha iyi performans sergiledikleri ve diğer renk kıyafet giyen sporcuların performanslarının daha düşük olduğu sonucuna ulaşmışlardır. Bu durum kırmızı rengin fiziksel, zihinsel ve ruhsal gelişimi sağlayan spor dallarında başarı etkisini arttırması nedeniyle olumlu bir psikolojik etki yarattığı sonucuna işaret etmekte ve şiddet uygulamadığını ifade eden çocuklar açısından araştırma sonuçlarıyla örtüşmektedir. Araştırma sonuçlarına göre katılımcıların, kırmızı renk uyaranına ilişkin çağrışımlarının rengin ilişkili olduğu öğrenilmiş kavram ya da temalarla olan etkileşiminden ziyade, şiddete olan eğilimlerine göre farklılık göstermesi dikkat çekicidir. Bu doğrultuda araştırma, kişinin sosyal ya da çevresel yaşam düzeyine bağlı olarak kırmızı rengin çağrışımlarının şiddet eğiliminden etkilendiğinin bir göstergesi olarak önem taşımaktadır.

Araştırma sonuçları kırmızı rengin 11-12 yaş çocuklar üzerindeki simgesel çağrışımlarının, şiddet uyguladığını ve şiddet uygulamadığını ifade eden her iki gruptaki çocuklar açısından farklılaşmadığını göstermektedir. Koca (2002), kırmızının özellikle Türklerin rengi olduğunu, Karahanlı ve Selçuklu hükümdarlarının bayrakları, tuğları, saltanat şemsiyeleri, otağları ve giydikleri çizmelerin hep kırmızı renkte olduğunu vurgulamaktadır. Uçar (2004), kırmızının bayrak, başkaldırı ve devrimin rengi olduğunu; Mazlum (2011) ise, kırmızı rengin Türk Bayrağının rengi olması nedeniyle Vatanseverlik duygularını kamçıladığını ifade etmektedir. Diğer taraftan araştırma sonuçları şiddet uyguladığını ifade eden çocukların genel olarak kırmızı rengi olumsuz kavramlarla ilişkilendirseler de düşük bir oranda kırmızı rengi olumlu kavramsal çağrışımlar (aşk, kalp, adalet vb.) açısından da değerlendirdikleri sonucunu ortaya koymuştur. Jalil, Yunus ve Said (2013), öğrenme sürecini zenginleştirmede kritik öneme sahip görsel bir pekiştirme öğesi olarak tanımladığı renk kavramının, çevreyi öğrenmek için uygun bir renk bulma, insan tercihi, algılama ve duygusal reaksiyonların farklılıklarını içermesi gibi nedenlerden dolayı karmaşık bir süreç olduğunu ifade etmektedirler. Bu durum şiddet uyguladığını ifade eden çocukların bir kısmının kendilerini genel anlamda mutlu olarak değerlendirmelerine karşın; diğer kısmının şiddet uygulamadığını ifade eden çocuklara göre kendilerini olumsuz bir psikoloji ile değerlendirmelerinin bir sonucu olarak kabul edilebilir. Dolayısıyla da kırmızı renk uyaranının karmaşık duygusal süreçlerden etkilendiği ve rengin anlamının ve etkisinin kişinin içinde bulunduğu duygu, düşünce ve davranışa ilişkin belirli şartlarla ilgili olduğu söylenebilir. geliştirilmiştir:

$\mathrm{Bu}$ bilgiler 1şı̆̆ında araştırmanın sonuçları dikkate alınarak aşağıdaki öneriler 
1) Çocuklarla çalışan eğitimcilerin çocuklarda renk bilinci oluşturmak ve renk-duygu ilişkisini kavratmak amacıyla farklı sanatsal yöntem ve tekniklerle ilişkilendirilmiş sınıf içi etkinlikler düzenlemeleri gerektiği düşünülmektedir. Renklerin çağrışımları, psikolojik anlamları ve duygu, davranış üzerindeki psikolojik etkisinin farklı sanatsal etkinliklerle desteklendiği çalışmaların, öğrencilerin duygusal ve psikolojik gelişimleri ile kendilerini ifade etme becerilerinin gelişimine olumlu katkı sağlayacağ düşünülmektedir.

2) Renkler kişinin bilişsel, duygusal ve davranışsal becerilerinin gelişmesine ve çevresini algılama biçiminin farklılaşmasına neden olduğundan, renklerin olumsuz etkisinin ortadan kaldırılması ve duyguların dışavurumunu sağlayan farklı sanatsal yöntemler aracılığıyla olumlu davranış biçimiyle sonuçlanacak kaçınma davranışının nasıl gerçekleşeceği konusunda öğrenciler bilinçlendirilmelidir.

3) Rengin anlamının ve etkisinin kişinin içinde bulunduğu duygu, düşünce ve davranışa ilişkin belirli şartlarla ilgili olduğu gerekçesiyle, özellikle şiddet eğilimi olan çocuklarda şiddetten kaçınma davranışına yol açacak sosyal bağlamların yaratılması, bu çocuklarda sanatsal gelişim bağlamında renk terapisi yoluyla kırmızı rengin olumlu duygularla ilişkilendirilmesinin sağlanması gerektiği düşünülmektedir.

\section{KAYNAKÇA}

Abbasi, M. A., Talaei, A., Talaei, A. ve Rezaei, A. (2014). The Use of appropriate colors in the design of children's room: A short review. International Journal of Pediatrics, 2(4.1), 305312.

Bagchi, R. ve Cheema, A. (2013). The effect of red background color on willingness-to-pay: The moderating role of selling mechanism. Journal of Consumer Research, 39(5), 947-960.

Buechner, V. L. ve Maier, M. A. (2016). Not always a matter of context: direct effects of red on arousal but context-dependent moderations on valence. PeerJ, 4:e2515.

Buyurgan, S. ve Demirel, İ. N. (2013). Effects of television series on 11-12 years old children. Turkish Journal of Teacher Education, 2(1), 19-35.

Can, A. (2014). SPSS ile bilimsel araştırma sürecinde nicel veri analizi (2. bs.). Ankara: Pegem Akademi.

Creswell, J. W., \& Plano Clark, V. L. (2015). Karama yöntem araştırmaları, tasarımı ve yürütülmesi (Y. Dede ve S. B. Demir, Çev.). Ankara: Anı Yayıncılık.

DiRocco, D. (2012). The Effect of the Color Red on Test Anxiety and Academic Achievement. 11.03 .2018 tarihinde https://pdfs.semanticscholar.org/0e7a/2dc4cd7384600684e7b8e6a525d7999f0c1d.pdf adresinden edinilmiştir.

Drummond, P. D. ve Quah, S. H. (2001). The effect of expressing anger on cardiovascular reactivity and facial blood flow in Chinese and Caucasians. Psychophysiology, 38(2), 190196.

Elliot, A. J. (2015). Color and psychological functioning: are view of theoretical and empirical work. Frontiers in Psychology, 6(368), 1-8.

Elliot, A. J. ve Maier, M. A. (2007). Color and psychological functioning. Association for Psychological Science, 16(5), 250-254. 
Elliot, A. J., Maier, M. A., Moller, A. C., Friedman, R. ve Meinhardt, J. (2007) . Color and psychological functioning: The effect of red on performance attainment. Journal of Experimental Psychology: General, 136(1), 154-168.

Elliot, A. J. ve Niesta, D. (2008). Romantic red: Red enhances men's attraction to women. Journal of Personality and Social Psychology, 95(5), 1150-1164.

EMPATI, (2003). Yaş gelişim özellikleri (11-14 yaş arası). EKIN Koleji PDR Servisi, 3(17): 1-8.

Gan, T, Fang, W. ve Ge, L. (2016). Colours' 1mpact on morality: Evidence from event-related potentials. Scientific Reports, Scientific Reports. 6, 38373.

Gueguen, N., Jacob, C., Lourel, M. ve Pascual, A. (2012). When drivers see red: Car color frustrators and drivers' aggressiveness. Aggressive Behavior, 38(2), 166-169.

Hill, R. A. ve Barton, R. A. (2005). Psychology: Red enhances human performance in contests, Nature International journal of Science, 435, 293.

Jalil, N. A., Yunus, R. M. ve Said, N. S. (2013). Students' colour perception and preference: An empirical analysis of its relationship. Procedia-Social and Behavioral Sciences, 90, 575582.

Kaya, N. ve Epps, H. H. (2004). Color-emotion associations: Past experience and personal preference. 20.03.2018 tarihinde http://citeseerx.ist.psu.edu/viewdoc/download?doi=10.1.1.616.6634\&rep=rep1\&type=pdf adresinden edinilmiştir.

Keskar, G. (2010). Color psychology and its effect on human behavior. paintindia, 60(5): 61-64.

Koca, S. (2002). Eski Türklerde bayram ve festivaller. Ankara: Yeni Türkiye Yayınları.

Kuniecki, M., Pilarczyk, J. ve Wichary, S. (2015). The color red attracts attention in an emotional context. An ERP study. Frontiers in Human Neuroscience, 9(212), 1-14.

Küçükşen Öner, F. (2010). İlköğretim öğrencilerinin resimlerinde renk ve duygu ilişkisi ve kırmızının öğrencilerde yarattı̆̆ı kavramsal ve simgesel çağrışımlar, Yayınlanmamış Doktora Tezi, Marmara Üniversitesi Eğitim Bilimleri Enstitüsü, İstanbul.

Little, A. C. ve Hill, R. A. (2007). Attribution to red suggests special role in dominance signaling. Journal of Evolutionary Psychology, 5(1-4), 161-168.

Mazlum, Ö. (2011). Rengin kültürel çağrışımları. Dumlupınar Üniversitesi Sosyal Bilimler Dergisi, $31,125-138$.

Meier, B. P., D’Agostino, P. R., Elliot, A. J., Maier, M. A. ve Wilkowski, B. M. (2012). Color in context: Psychological context moderates the influence of red on approach- and avoidancemotivated behavior. PLOS ONE, 7(7), e40333.

Miles, M. B. ve Huberman, A. M. (1994). Qualitative data analysis: An expveed sourcebook. (2nd Edition). California: SAGE Publications.

Mohebbi, M. (2014). Investigating the gender-based colour preference in children. Procedia-Social and Behavioral Sciences, 112: 827-831.

Olsen, J. (2010). The Effect of color on conscious and unconscious cognition. 04.03.2018 tarihinde http://repository.cmu.edu/cgi/viewcontent.cgi?article=1079\&context=hsshonors adresinden edinilmiştir. 
Oyama, T. (2003). Affective and symbolic meanings of color and form: experimental psychological approaches. Empirical Studies of the Arts, 21(2): 137-142.

Özdemir, M. (2010). Nitel veri analizi: Sosyal bilimlerde yöntembilim sorunsalı üzerine bir çalışma. Eskişehir Osmangazi Üniversitesi Sosyal Bilimler Dergisi, 11(1): 323-343.

Pekdoğan, S. (2018). Okul öncesi öğretmenlerinin farklılıklara saygi eğitimi konusundaki görüşlerinin incelenmesi. Elektronik Sosyal Bilimler Dergisi, 17(65): 90-102.

Pellegrini, R.J., Schauss, A.G., Miller, M.E. (1981). Room color and aggression in a criminal detention holding cell: A test of the "Tranquilizing Pink" hypothesis. Journal of Orthomolecular Psychiatry, 10(3), 174-181.

Singh, S. (2006). Impact of color on marketing. Management Decision, 44(6): 783-789.

Shorenstein, D. (2016). The Effect of Color on Monetary Decisions Regarding Risk. 17.04. 2018 tarihinde https://cogsci.yale.edu/sites/default/files/files/Thesis2016Shorenstein.pdf adresinden edinilmiştir.

Teddlie, C., ve Yu, F. (2007). Mixed methods sampling: A typology with examples. Journal of Mixed Methods Research, 1(1): 77-100.

Uçar, T. F. (2004). Görsel iletişim ve grafik tasarım. İstanbul: İnkılap Yayınevi.

Valdez, P. ve Mehrabian, A. (1994). Effects of color on emotions. Journal of Experimental Psychology: General, 123(4): 394-409.

Wardono, P., Hibino, H. ve Koyama, S. (2012). Effects of interior colors, lighting and decors on perceived sociability, emotion and behavior related to social dining, Procedia-Social and Behavioral Sciences, 38, 362-372.

Whitfield, T. W. ve Wiltshire, T. J. (1990). Color psychology: A critical review. Genetic, Social \& General Psychology Monographs, 116(4), 385-411.

Wiedemann, D., Burt, D. M., Hill, R. A. ve Barton, R. A. (2015). Red clothing increases perceived dominance, aggression and anger. Biology Letters, 11(5), 1-4. 